\title{
The effect of intravaginal electrical stimulation on the quality of life and changes in function and anatomy of pelvic floor in women with stress urinary incontinence
}

Carneiro Erica1 , Araùjo Nazete ${ }^{1}$, Cader Samaria1, Fonseca Aluizio², Bittencourt Leila ${ }^{1}$, Mendes Stefanie ${ }^{3}$, Dantas Estélio ${ }^{1}$

Bioscience Lab in Human Motricity. Castelo Branco University (CBU). Rio de Janeiro

${ }^{1}$ Castelo Branco University (CBU), Rio de Janeiro, Bioscience Lab in Human Motricity ${ }^{2}$ Urology Physician, Master's Degree in Medicine Course of São Paulo University (USP),

${ }^{3}$ Physical Therapy Undergraduate Course student at Pará State University (Uepa)

\section{Summary}

Introduction: Urinary incontinence (UI), according to the Committee of the International Continence Society Standards, is defined as any involuntary urine loss associated to exertion conditions. This urine loss can be called Stress Urinary Incontinence (SUI) and when the detrusor muscle becomes inactive.

Material and methods: The goal of this study was verifying intravaginal electrical stimulation effects on bladder floor mobility, pelvic floor muscles' width, their contraction ability and the quality of life of 40 women whose age ranged from 35 to 55 and who were diagnosed with Stress Urinary Incontinence disorder. They were split into two groups: Geletro (underwent 16 perineal electrical stimulation sessions) and control group, Gc (no intervention). The variables were respectively evaluated by the following instruments: transvaginal ultrassonography (Toshiba trademark), Phenix electromyographic biofeedback and King's Health Questionnaire.

Results: The results were bladder floor mobility reduction $(\Delta \%=-9,13 \%, \mathrm{p}=0,0930)$, width increase on pelvic floor muscles $(\Delta \%=11,64 \%, p=0,2924)$, both not significant, muscle strength increase due to biofeedback $(\Delta \%=60,49 \%, \mathrm{p}=0,0001)$ and to AFA* $(\Delta \%$ $=24,53 \%, p=0,0001)$, and significant decrease of all questionnaire scores: DOM $1(\Delta \%$ $=-50,00 \%, \mathrm{p}=0,000)$, DOM $2(\Delta \%=-55,14 \%, \mathrm{p}=0,005)$, DOM $3(\Delta \%=-74,98 \%, \mathrm{p}=$ $0,002)$, DOM $4(\Delta \%=-73,87 \%, \mathrm{p}=0,002)$, DOM $5(\Delta \%=-68,91 \%, \mathrm{p}=0,001)$, DOM 6 $(\Delta \%=-85,90 \%, \mathrm{p}=0,000)$, DOM $7(\Delta \%=-72,48 \%, \mathrm{p}=0,014)$, DOM $8(\Delta \%=-71,88 \%, \mathrm{p}=$ 0,030), DOM $9(\Delta \%=-73,29 \%, p=0,023)$.

Conclusions: The Geletro group in comparison to the Gc showed that intravaginal electrical stimulation improved the pelvic floor anatomically and functionally and also the quality of life of Geletro group. Stress Urinary Incontinence improvement could only be subjectively demonstrated.

Keywords: bladder neck, pelvic floor, quality of life, intravaginal electrical stimulation therapy 


\section{Introduction}

Urinary incontinence (UI), according to the Committee of the International Continence Society Standards, is defined as any involuntary urine loss associated to exertion conditions. This urine loss can be called Stress Urinary Incontinence (SUI) and when the detrusor muscle becomes inactive [1,2].

Urinary continence depends on passive and active factors. The passive mechanism is dependent primarily on the uterus-vesicle junction, secondarily by the proximal urethra, and its efficiency is directly related to these structures' position [3]. As to the active structures, they are the neuromuscular components and are responsible for muscle tone and contraction in response to the sudden abdominal pressure rise [4].

The pelvic floor muscles (PFM) are responsible for maintaining the bladder neck in its intra-abdominal position. It is expected that a great number of patients who present pelvic floor weakness will also present urethral hypermobility and, as a consequence, SUI [5]. Borges [6] also says that the consequences of pelvic looseness are urinary and fecal incontinence, as well as the prolapse of pelvic organs, such as the bladder and the rectum.

To Almeida [7], the majority of patients who present SUI have an anatomical malformation which causes hypermobility of the urethra and the bladder neck. Talking about UI is not common neither among physicians nor with other health care professionals [8]. Thirty to fifty percent of people who present urinary incontinence (UI) do not mention it to their physicians, who turn out to ignore this pathology [7]. Silently, these people have their quality of life (QL) affected in many ways, presenting symptoms such as depression, distress, morbid irritation, constant anxiety about restrooms' availability, being ashamed of their urine smell, and even presenting skin lesions such as ammoniacal dermatitis and repeated urinary infections $[9,10]$.

SUI treatment has historically been surgical; however, although there is quality of life (QL) drop due to urine loss, some women avoid being submitted to surgical procedure because of surgery risks, and for other women, surgical anesthesia is not indicated [11].

More than 100 surgical methods have already been described in the literature for SUI treatment, and this calls attention to the fact that there is no ideal surgical procedure for treating this health problem [7].

Among various conservative treatment methods for SUI, focus is given to intravaginal electrical stimulation (ES) which can be used for SUI and detrusor muscle hyperactivity treatments. Its main goal is inhibiting detrusor muscle activity; however it is also an efficient option for the strengthening of pelvic floor muscles (PFM) [12]. ES used for inhibiting the detrusor muscles and the PFM stimulation happen via reflex through the puden- dum nerve's sensitive routes and the latter occurs in an indirect way [13].

The goal of this research was investigating the possibility of specific perineal contraction training using ES as a treatment modality for women who present SUI and that can promote PFM strengthening, and therefore influencing the bladder neck mobility as well as interfering in these women's quality of life.

\section{Material and methods}

Research was experimental since its methodological design includes variables handling, containing a control group and following randomized principles, according to technical possibilities associated with its development. It was based on cause and effect relationship guided by imposing independent variables over other dependent variables.

Experimental procedures were done according to guidelines from Helsinki's Declaration, Nuremberg's Code and the local Ethics Comittee (IRB number 0176/2008). After approval, all individuals participating in the research signed the Authorized Participation Term, and attended at Centro de Tratamento Urológico, in the city of Belém, State of Pará (Brazil), from October, 2008 to May, 2009.

Women whose age ranged between 35 to 55 years-old and who presented SUI due to prevailing bladder neck hypermobility, presenting no neurological condition of any kind, were included in this research. Women who presented SUI due to intrinsic insufficiency, detrusor muscle hyperactivity, patients who took medication that could potentially interfere in UI, who presented surgical correction previous to SUI and/or genital prolapses onset, diabetic patients, pregnant women and those whose body mass index (BMI) was superior to 35 were excluded from the research.

All women were assigned to treatment by urology or gynecology physicians when they presented SUI complaint.

All women who were indicated to treatment were evaluated and after inclusion and exclusion criteria were applied, only forty women were approved to participate in the research, and they were divided into two groups at random: GEletro, $n=20$ with the age 47,5 $\pm 3,22$ yearsold, delivery number $1,65 \pm 0,8$, SUI disorder length 3,15 $\pm 1,35$ years and the control group Gc, $n=20$ with the age $45,25 \pm 5,6$ years-old, delivery number $0,75 \pm 1,0$, SUI disorder length $3,70 \pm 2,20$ years.

As a diagnostic procedure, all participants in the sample were submitted to urodynamic study since its importance for etiologic diagnosis for SUI has greatly increased because it is through it that bladder and vesicourethral sphincter complex performances are analyzed. They were also submitted to transvaginal ultrasound in 
order to determine UI type, bladder neck mobility and anus elevator muscle width.

Later on, women were asked to fill in an evaluation form which asked for clinical history and physical examination of the sample, and they also received instructions on anatomical position and function of pelvic muscles and how they work. They were also instructed on how they could look to their perineum using a hand mirror and how they could touch their perineum central fibrous nodule using their fingers. The goal for this intervention was training patients and enabling consciousness of this body area, the latter being extremely necessary for the program effectiveness.

The pelvic floor muscles' contraction ability was evaluated using FEP, the Ortiz scale [15] and Phenix electromyographic biofeedback (USB 4 model, VIVALTS PS company, made in Paris-France).

In order to evaluate SUI interference on QL of the women participating in the study, they answered to King's Health Questionnaire (KHQ) which is a specific evaluation procedure to UI and was validated and translated to the Portuguese language [16].

The KHQ contains 21 questions organized into eight areas: general health awareness, UI impact on one's health, physical and social limitations, personal relationship, emotions, sleep and disposition, as well as two scales used for self-definition of UI severity and intensity of urinary symptoms. Score ranges from 0 to 100 , however KHQ scores and QL are inversely proportionate [17].

Intervention occurred in the following order: Geletro participated in ES program associated to voluntary con- tractions of pelvic floor muscles (PFM). The machine used for ES was Dualpex 961 (from Quark company), and frequency of $50 \mathrm{~Hz}$, pulse width of $700 \mu \mathrm{s}$, up and down time of 2 seconds, maintenance time of 6 seconds, and rest time of 12 seconds [18]. Gc was also evaluated but no treatment was applied to it during the period research was taken because it was part of a waiting line list.

Evaluated parameters were: contraction ability, bladder neck mobility, anus elevator muscle width and QL.

For data analysis, descriptive statistics with range and standard deviation were used. Sample normality was evaluated with Shapiro-Wilk test and variance homogeneity of Levene's test. For analyzing varied answers, intra-group analysis and paired t-Student or Wilcoxon test were used, when appropriate. For inter-group evaluation, the Kruskal Wallis non-parametric test was used followed by multiple comparisons done by Mann-Whitney test or ANOVA two way parametric test, and Post Hoc of Tukey after that. $\mathrm{P}<0.05$ level was adopted for statistical significance. Data were analyzed using Excel program and SPSS 14.0 statistical package.

\section{Results}

Descriptive analysis of anatomical-functional changes in the pelvic floor of the sample and its normality are presented in Table 1. It was observed that homogeneous distribution related to urinary bladder neck mobility (Gc and Geletro), PFM's width (Gc and Geletro) and its contraction ability evaluated by biofeedback (Geletro) took place.

Tab. 1. Morphofunctional characteristics of the pelvic floor of the sample

\begin{tabular}{|c|c|c|c|c|c|c|c|}
\hline \multirow{2}{*}{\multicolumn{2}{|c|}{ Parameter }} & \multicolumn{3}{|c|}{$\begin{array}{l}\text { Gc } \\
\text { CG }\end{array}$} & \multicolumn{3}{|c|}{$\begin{array}{c}\text { Geletro } \\
\text { EG }\end{array}$} \\
\hline & & Average & $\mathbf{s}$ & p-SW value & Average & $\mathbf{s}$ & p-SW value \\
\hline \multirow{2}{*}{$\begin{array}{l}\text { Urinary Bladder } \\
\text { Neck }\end{array}$} & pre-test & 16,74 & 4,27 & 0,607 & 17,30 & 4,56 & 0,924 \\
\hline & post-test & 17,53 & 4,35 & & 15,72 & 4,15 & \multirow{3}{*}{0,319} \\
\hline \multirow{2}{*}{ Width } & pre-test & 11,52 & 1,54 & 0,076 & 10,35 & 1,38 & \\
\hline & post-test & 11,87 & 1,75 & & 11,56 & 1,81 & \\
\hline \multirow{2}{*}{$\begin{array}{l}\text { Biofeedback } \\
\text { Contraction }\end{array}$} & pre-test & 8,30 & 5,29 & $\mathbf{0 , 0 0 7}$ & 8,10 & 4,72 & 0,064 \\
\hline & post-test & 8,25 & 5,41 & & 13,00 & 6,09 & \multirow{3}{*}{0,018} \\
\hline \multirow{2}{*}{$\mathrm{AFA}^{*}$ Contraction } & pre-test & 2,55 & 1,10 & $\mathbf{0 , 0 0 6}$ & 2,65 & 0,88 & \\
\hline & post-test & 2,60 & 1,10 & & 3,30 & 0,57 & \\
\hline
\end{tabular}

Urinary Bladder: Urinary bladder neck (in milimiters); Width: Width of pelvic floor muscle (in milimiters); Biofeedback contraction: contraction ability of the pelvic floor muscles evaluated by Phenix biofeedback ( in $\mu \mathrm{v}$ ); AFA* contraction: contraction ability of the pelvic floor muscles evaluated by the AFA* (degree); SW: Shapiro Wilk; Geletro: electrotherapy group; Gc: control group.

Table 2 shows descriptive analysis and Shapiro-Wilk (normality) of sample's QL analysis. It could be observed that the sample obtained heterogeneous distribu- tion of all sample data $(p<0,05)$, except for DOM2 and DOM9 (CG). 
Tab. 2. Quality of Life of sample groups, by King's Health Questionnaire

\begin{tabular}{|c|c|c|c|c|c|c|c|}
\hline & & & & & & & \\
\hline & & Average & s & p-SW value & Average & $\mathbf{S}$ & p-SW value \\
\hline DOM & pre-test & 28,75 & 14,68 & 0,000 & 40,00 & 14,96 & 0,000 \\
\hline DOMI & post-test & 28,75 & 14,68 & & 20,00 & 10,26 & \\
\hline & pre-test & 55,41 & 28,13 & 0,067 & 64,97 & 24,73 & 0,005 \\
\hline Dethe & post-test & 55,41 & 28,13 & & 29,14 & 16,98 & \\
\hline DOM & pre-test & 26,63 & 23,76 & 0,004 & 26,62 & 19,72 & 0,002 \\
\hline 8017 & post-test & 26,63 & 23,76 & & 6,66 & 13,67 & \\
\hline DOM & pre-test & 31,66 & 29,07 & 0,005 & 42,48 & 25,64 & 0,002 \\
\hline 50194 & post-test & 29,16 & 28,03 & & 11,10 & 15,70 & \\
\hline DOM 5 & pre-test & 18,83 & 25,74 & 0,000 & 24,09 & 27,39 & 0,001 \\
\hline DOIII & post-test & 18,83 & 25,74 & & 7,49 & 13,74 & \\
\hline DOM & pre-test & 27,50 & 35,57 & 0,000 & 32,48 & 27,82 & 0,000 \\
\hline Dotro & post-test & 27,50 & 35,57 & & 4,58 & 11,29 & \\
\hline DOM 7 & pre-test & 30,52 & 26,84 & 0,017 & 33,28 & 23,85 & 0,014 \\
\hline DOMI & post-test & 30,52 & 26,84 & & 9,16 & 14,77 & \\
\hline DOY & pre-test & 25,55 & 20,02 & 0,014 & 26,65 & 21,90 & 0,030 \\
\hline DO1910 & post-test & 25,55 & 20,02 & & 7,49 & 13,75 & \\
\hline DOM 9 & pre-test & 34,61 & 23,91 & 0094 & 40,56 & 28,81 & 0023 \\
\hline DOMY & \begin{tabular}{|l|} 
post-test \\
\end{tabular} & 34,61 & 23,91 & 0,074 & 10,83 & 11,75 & \\
\hline
\end{tabular}

DOM1: general health; DOM2: incontinence impact; DOM3: daily activities limitation; DOM4: physical limitation; DOM5: social limitation; DOM6: personal relationships; DOM7: emotions; DOM8: sleep and mood; DOM9: severity measurement; Geletro: electrotherapy group; Gc: control group

Table 3 represents urination symptoms which took place before and after protocol application to Control Group. In general, symptoms did not change after protocol application, and SUI and incontinence during sex- ual intercourse (which are respectively, fifth and seventh presented symptoms) occurred in most women from the sample group.

Tab. 3. Voiding Symptomatology of Control Group

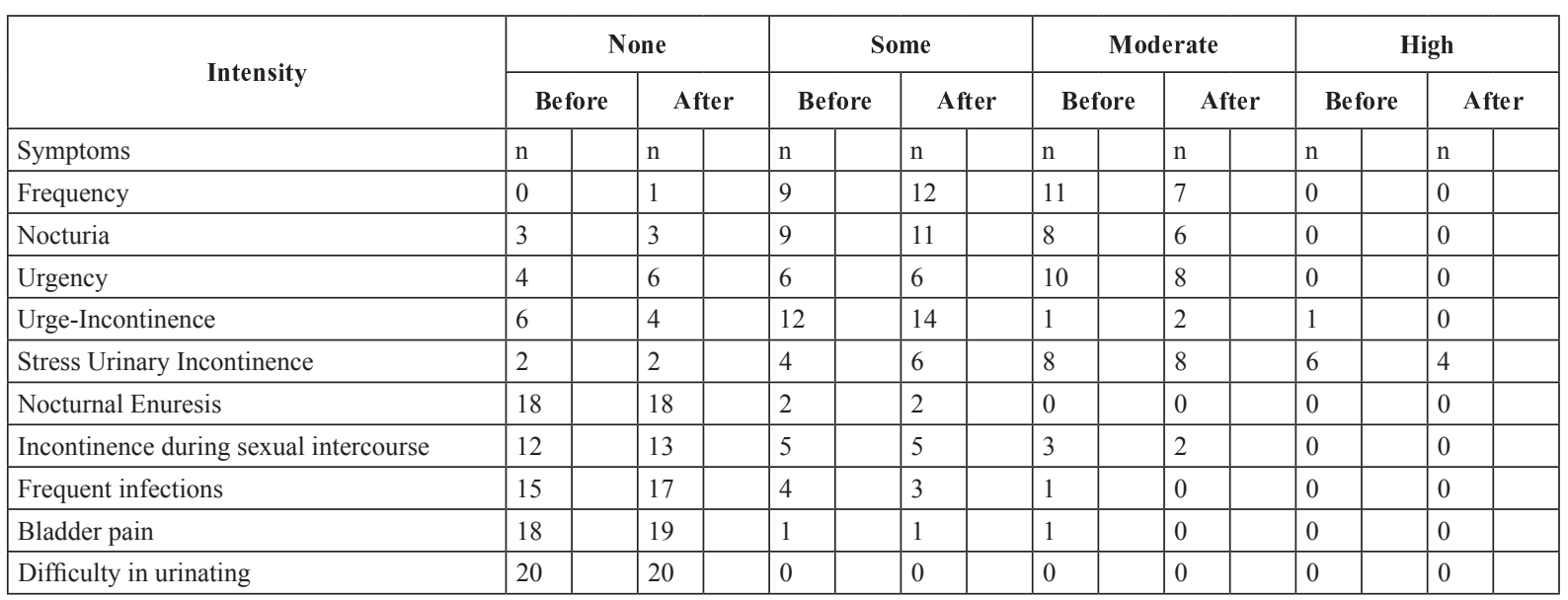

Table 4 represents voiding symptoms before and after protocol application in Geletro. At this table, SUI also occurs in moderate and high intensity in most women from the sample group. Urgency and urge-incontinence also occur in high frequency, but the three symptoms become much lower in the post-test. 
Tab. 4. Voiding Symptomatology of Control Group

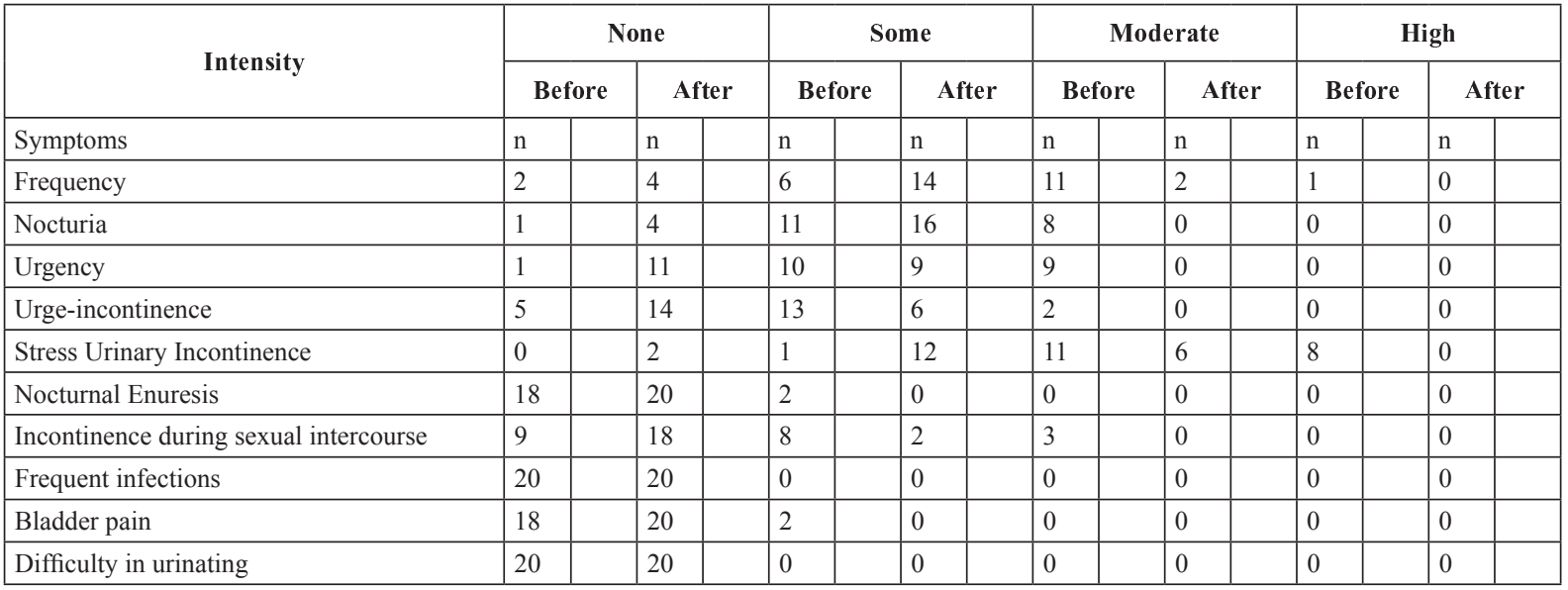

In table 5, intra- and inter-group analysis of QL is presented by percentage delta $(\Delta \%)$. In intra-group evaluation, one can notice that the ES Group, in its posttest, obtained significant improvement $(p<0,05)$ in all domains $(p=0,0001)$. In inter-group analysis, there was significant improvement $(\mathrm{p}<0,05)$ in Geletro post-test when compared to $\mathrm{CG}$ post-test in the following domains: DOM1 ( $\mathrm{p}=0,036)$, DOM $2(\mathrm{p}=0,0001)$, DOM 3 $(\mathrm{p}=0,001)$, DOM $4(\mathrm{p}=0,004)$, DOM $6(\mathrm{p}=0,006)$, DOM $7(\mathrm{p}=0,001)$, DOM $8(\mathrm{p}=0,0001)$ and DOM9 $(\mathrm{p}=0,0001)$.

Tab. 5. Variation of QL domains, intra- and intergroups, expressed in percentage values $(\Delta \%)$

\begin{tabular}{|c|c|c|}
\hline & $\Delta \%$ - ElectrotherapyC & $\Delta \%-C G$ \\
\hline DOM 1 & $-50,00 * \#$ & 0,00 \\
\hline DOM 2 & $-55,14 * \#$ & 0,00 \\
\hline DOM 3 & $-74,98 * \#$ & 0,00 \\
\hline DOM 4 & $-73,87 * \#$ & $-7,90$ \\
\hline DOM 5 & $-68,91 *$ & 0,00 \\
\hline DOM 6 & $-85,90 * \#$ & 0,00 \\
\hline DOM 7 & $-72,48 * \#$ & 0,00 \\
\hline DOM 8 & $-71,88 * \#$ & 0,00 \\
\hline DOM9 & $-73,29 * \#$ & 0,00 \\
\hline \multicolumn{3}{|c|}{${ }^{*} \mathrm{p}<0,05$; pre $v s$. post } \\
\hline \multicolumn{3}{|c|}{$\# \mathrm{p}<0,05 ;$ post vs. post } \\
\hline \multicolumn{3}{|c|}{$\begin{array}{l}\text { DOM1: general health; DOM2: incontinence impact; DOM3: daily ac- } \\
\text { tivity limitation; DOM4: physical limitation; DOM5: social limitation; } \\
\text { DOM6: personal relationships; DOM7: emotions; DOM8: sleep and } \\
\text { mood; DOM9: severity measurement; Geletro: electrotherapy group; } \\
\text { Gc: control group }\end{array}$} \\
\hline
\end{tabular}

Figure 1 compares anatomical-functional parameters of the pelvic floor in intra and intergroup analysis, presented by delta percentage $(\Delta \%)$. In intra-group analysis, significant and satisfactory improvement could be observed $(\mathrm{p}<0,05)$ in the Geletro post-test in all variables, which were: urinary bladder neck $(p=0,001)$, width $(p=0,0001)$, electrical stimulation $(p=0,0001)$ and contractility $(p=0,0001)$; however the Gc presented significant and unsatisfactory increase $(\mathrm{p}=0,002)$ in the urinary bladder neck variable in its post-test as well as it did not obtain any satisfactory improvement in the variables. As for inter-groups comparisons, it was observed that there was significant improvement in Geletro (post-test), only in electrical stimulation $(0,01)$ and contractility $(\mathrm{p}=0,05)$ variables.

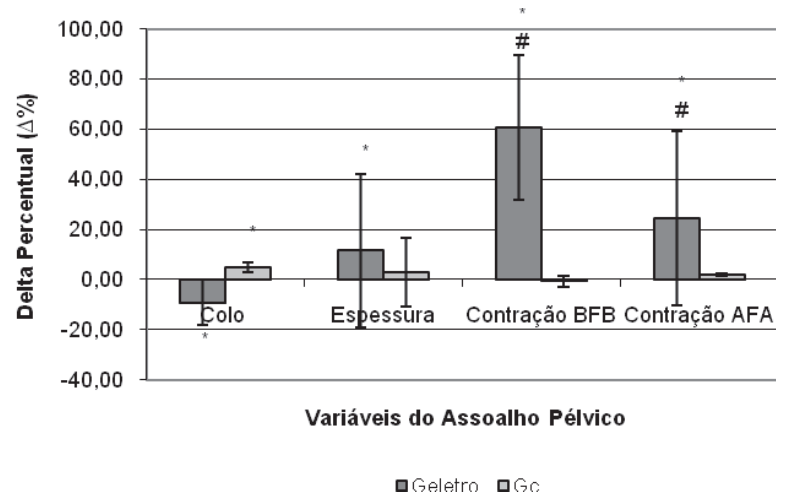

${ }^{*} \mathrm{p}<0,05$; pre $v s$. post

$\# \mathrm{p}<0,05$; post vs. Post

Colo: Bladder Floor: Bladder floor mobility (in milimiters)

Espessura Pelvic floor muscles' width (in milimiters); Contração BFB: contraction ability of the pelvic floor muscles evaluated by Phenix biofeedback (in $\mu \mathrm{v}$ ); Contração AFA*: contraction ability of the pelvic floor muscles evaluated by AFA* (in degree); Geletro: electrotherapy group; Gc: control group

Fig. 1. Comparison of pelvic floor changes in intra- and inter-groups analysis, expressed in percentage values $(\Delta \%)$.

\section{Discussion}

ES is generally used in strengthening weak muscles and in promoting their functional recovery, it can be applied to muscles while there is (or there is not) functional 
movement [19]. When ES is used in PFM, it determines increase in contraction strength of anus elevator muscle and in functional length of urethra, therefore improving abdominal pressure transmission [20].

Barroso [21] says ES causes contractions of PFM, increasing fast-contraction fibers which are activated in stress situations. In his research, significant improvement could be observed.

Herman [22] shows in his study that there was no significant difference in urinary bladder neck mobility before and after ES sessions $(\mathrm{p}=0,30)$ shown in ultrasound evaluation, but there was improvement in urine losses caused by stress, coming to the conclusion that transvaginal ES of pelvic floor is an effective and safe therapeutic method. These results were also found in Potrick's study [23], which also used ES and obtained significant reduction of urine loss frequency in most patients but there was no significant performance over PPE and bladder neck mobility.

In intra-group analysis of this study, there was significant and satisfactory improvement $(\mathrm{p}<0,05)$ in Geletro post-test related to bladder neck mobility $(\mathrm{p}=0,001)$. These results make it different from previously mentioned studies but they are close to those found in studies of Castro et al [24] (2008) in which exercises for pelvic floor, ES and vaginal cones in SUI were compared and findings were that all three methods are equally effective for SUI treatment, as observed through pad test, QL questionnaire, urodynamic study, daily urine loss numbers and subjective responses.

Rett [25] says that strength and width of PFM are found in incontinent women suggesting neuromuscular lesion and therefore treatments that reeducate and make these muscles stronger should be a priority. It is observed that there was width increase in PFM $(\mathrm{p}=0,0001)$ as well as muscle strength increase when evaluated through biofeedback $(p=0,0001)$ and through FEP $(p=0,0001)$.

Turhannoglu [26] tested 27 women who presented stress urinary incontinence, treating them with ES, and he succeeded in reducing urine losses, urinary mictions per day, sanitary pads $(\mathrm{p}<0,001)$ and satisfactory results when using QL questionnaire $(\mathrm{p}<0,001)$.

In a study performed by Carramao [27], seventeen women who presented SUI were treated and the results were reduction of clinical complaint evaluated through a validated questionnaire, urodynamic improvement and FEP increase.

ES is also an effective method for promoting conscious awareness of pelvic floor [13]. In this study, women learned how to constrict this musculature proved through contraction capacity increase of PFM, verified by FEP and electromyography.

Rett [28] affirms that women who have difficulty in contracting PFM either by not feeling or by not sustain- ing contraction may have benefits when being submitted to ES.

Yamanishi et al [29] say that cure indexes for SUI treated with ES ranges around $35 \%$, and improvement rates range from $50 \%$ to $70 \%$; these data are comparable to this study in which results presented $70 \%$ of improvement (as observed in the symptoms table - Table 4) and that before treatment, $95 \%$ of women informed they had moderate or high intensity of urine loss due to stress, and after treatment, $30 \%$ said they had moderate urine loss and $70 \%$ had some or no urine loss. QL is proven to be affected in women who presented SUI; in an observational transverse study, Oliveira [17] came to the conclusion that most women who complained of SUI and urgeincontinence had QL somehow affected and even by not limiting their daily physical and social activities, most women in the study realized UI affects their perception of health and produces a negative impact in health status, jeopardizing sleep and mood.

In post-test, it was observed there was a significant decrease in all domain scores of the questionnaire (table 5). These results are comparable to those of Rett [25] who also obtained considerable drop on almost all scores except for DOM6 which corresponds to personal relationship domain.

\section{Conclusion}

Intravaginal electrical stimulation was identified as a good resource to lowering bladder neck mobility, increasing PFM's width and contraction ability of PFM of those subjects in the experimental group (Geletro) who underwent ES sessions, besides increasing perception and recruitment of PFM muscle fibers. There was decrease on scores in Quality of Life questionnaire which showed improvement of Geletro's QL. It is not possible to show SUI improvement objectively, but Table 4 of Geletro's symptomatology showed that SUI symptom was subjectively reduced.

* AFA stands for Functional Evaluation of the Pelvic Floor in the Portuquese language. The authors decided to mantain the Brazilian Portuquese acronym so that it would be easier to recognize it among Brazilian health care professional readers.

\section{References}

1. Rodrigues NC, Scherma D. Exercícios perineais, eletroestimulação e correção postural na incontinência urinária: estudo de casos. Fisioter Mov 2005 Jul/Sep; 18(3):23-9.

2. Frade AB, Auge APF, Macéa JR, Frade CL, Lunardelli JL, Lemos NLBM, Rossi LM, Aoki T. Estudo urodinâmico da pressão de perda ao esforço, nas posições ortostática e sentada, em mulheres com incontinência urinária. Rev Bras Ginecol Obstet 2007 Feb; 29(2):91-95.

3. Brandt FT. Estudo dos parâmetros ultra-sonográficos da uretra proximal e da mobilidade da junção uretrovesical 
em mulheres, visando estabelecer a importância clínica. (Tese de Livre-Docência). São Paulo: USP; 1999.

4. Oliveira E, Castro RA, Zucchi EVM, Araújo MP, Sartori MGF, Girão MJBC. Mecanismos de continência e teoria integral da incontinência urinária feminina. Femina 2007 Apr; 35(4):205-211.

5. Moreira SFS. Mobilidade do colo vesical e avaliação funcional do assoalho pélvico em mulheres continentes e com incontinência urinária de esforço, consoante o estado hormonal. Master's thesis on Gynecology. Escola Paulista de Medicina, São Paulo; 2000.

6. Borges BB, Serrano F, Pereira F. Episiotomia uso generalizado versus selectivo. Acta Med Port 2003 Feb; 16:447454.

7. Almeida M, Colaço J, Pereira HS, Vieira A, Gonçalves V, Retto H, Meirinho M. Colpopexia De Burch. Acta Med Port 2004; 17: 15-19.

8. Seleme M. Incontinência urinária um problema social de saúde pública. Rio de Janeiro: Universidade Federal do Rio de Janeiro; 2006.

9. Fonseca ESM, Camargo ALM, Castro RA, Sartori MGF, Fonseca MCM, Lima GR, Girão MJBC. Validação do questionário de qualidade de vida (King's Health Questionnaire) em mulheres brasileiras com incontinência urinária. Rev Bras Ginecol Obstet 2005 May;27(5):235242.

10. Auge AP, Zucchi CM, Costa FMP, Nunes K, Cunha LPM, Silva PVF, Ramos TU. Comparações entre os índices de qualidade de vida em mulheres com incontinência urinária submetidas ou não ao tratamento cirúrgico. Rev Bras Ginecol Obstet 2006 Jun; 28(6):352-357.

11. Amaro JL, Gameiro $\mathrm{MO}^{\circ}$, Padovani CA. Treatment of stress urinary incontinence (SUI) by intravaginal intravaginal electrical stimulation (IES) and pelvic floor physiotherapy. Int Urogynecol Journ 2003 Feb; 14(3): 204-208.

12. Baracho E, Moreno AL. Fisioterapia Aplicada à obstetrícia, uroginecologia e aspectos de mastologia. 3rd ed. Rio de Janeiro (Brazil): Guanabara Koogan; 2007. Chapter, A reeducação da musculatura do assoalho pélvico como método de tratamento conservador da incontinência urinária; p. 430-442.

13. Grosse D, Sengler J. Reeducação Perineal. São Paulo: Manole; 2002.

14. Palma PCR, Retto HF. Metanálise dos Métodos Diagnósticos da Incontinência Urinária De Esforço. Acta Med Port 1996;9:41-4.

15. Ortiz OC. Stress urinary in gynecological practice. Int J Gynaecol Obstet 2004; 86(1):6-16.

16. Tamanini JTN. et al. Validação Do "King's Health Questionnare" para o português em mulheres com Incontinência Urinaria. Saúd Púb; 2003.

17. Oliveira KAC, Rodrigues ABC, Paula AB. Técnicas fisioterapêuticas no tratamento e prevenção da incontinência urinária de esforço na mulher. Revista Eletrônica F@ pciência 2007; 1(1):31-40.

18. Rodrigues NC, Scherma D, Mesquita RA, De Oliveira J. Exercícios Perineais, Eletroestimulação E Correção Postural Na Incontinência Urinária - Estudo De Casos. Fisiot Movim $2005 \mathrm{Jul} / \mathrm{Sept} ; 18(3): 23-9$.

19. Kitchen S, Bazin S. Eletroterapia: Prática Baseada Em Evidências. 2nd ed. São Paulo: Manole; 2003.

20. Boaretto NL. Eletroterapia No Tratamento De Mulheres Com Incontinência Urinária de Esforço. Final Paper presented as a requirement for Undegraduate Degree Graduation from Assis Gurgacz College, Cascavel, PR; 2006 October 17.

21. Barroso JCV, Ramos JGL, Martins-Costa S, Sanches PRS, Muller AF. Transvaginal Intravaginal electrical stimulation In The Treatment of Urinary Incontinence. BJU Int. 2004 Feb; 93(3):319-23.

22. Herman V, Potrick BA, Palma PCR, Zanettini CL, Marques A, Rodrigues Netto NJ. Eletroestimulação Transvaginal do Assoalho Pélvico no Tratamento da Incontinência Urinária de Esforço: Avaliações Clínica e UltraSonográfica. Rev Assoc Med Bras 2003;49(4):401-5.

23. Potrick BA. Eletroestimulação Transvaginal do Assoalho Pélvico no Tratamento da Incontinência Urinária de Esforço: Avaliação Clinica, Urodinâmica E Ultra-Sonográfica. Campinas; 2002.

24. Castro RA, Arruda RM, Zanetti MRD, Santos PD, Sartori MGF, Girão MJBC. Single-Blind, Randomized, Controlled Trial Of Pelvic Floor Muscle Training, Intravaginal electrical stimulation, Vaginal Cones, And No Active Treatment In The Management Of Stress Urinary Incontinence Clinics. 2008 Aug;63(4):465-72.

25. Rett MT, Simões JA, Herrmann V, Gurgel MSC, Moraes SS. Women's Life Quality After Physical Therapy Treatment For Stress Urinary Incontinence. Rev Bras Ginecol Obstet 2007 Mar ;29(3):134-40.

26. Turhannoglu AD, Akay AF, Bayhan G, Karabulut, Z, Sahin H, Erdogan F, Bircan K. Transvaginal Intravaginal electrical stimulation In Female Genuine Stress Incontinence. Journ Phys Ther Sci 2000;12:75-79.

27. Carramao SS, Pacetta AM, Carramao S, Barros ACSD, Mantesse JC. Avaliacão da Eletroestimulação na Terapêutica da Incontinência Urinária de Esforço Feminina/ The Role Of The Pelvic Floor Intravaginal electrical stimulation In Treatment Of Female Of Stress Urinary Incontinence. Rev Ginecol Obstet 2003 Oct-Dec; 14(4):166-9.

28. Rett MT, Vale JR, Andrade CF, Simões JA. Abordagem Fisioterápica No Tratamento Da Incontinencia Urinaria De Esforço Feminina. Femina 2008 Apr; 36(4):209-214.

29. Yamanishi T, Yasuda K, Sakakibara R, Hattori T, Suda S. Randomized Double-Blind Study Of Intravaginal electrical stimulation For Urinary Incontinence Due To Detrusor Overactivity. Urology 2000 Mar; 55(3):353-7. 